\title{
The Effect of the Relationship among Leg Volume, Leg Mass and Flexibility on Success in University Student Elite Gymnasts
}

\author{
Dede Baştürk ${ }^{1} \&$ İrfan Marangoz ${ }^{1, *}$ \\ ${ }^{1}$ School of Physical Education and Sports, University of Kırşehir Ahi Evran, Kırşehir, Turkey \\ *Correspondence: School of Physical Education and Sports, University Kırşehir of Ahi Evran, Kırşehir, Turkey. Tel: \\ 90-506-632-2100. E-mail: imarangoz@ahievran.edu.tr
}

Received: June 19, 2018

Accepted: July 12, $2018 \quad$ Online Published: August 3, 2018

doi:10.5430/wje.v8n4p47

URL: https://doi.org/10.5430/wje.v8n4p47

\begin{abstract}
This study aims to analyze the effect of the relationship among leg volume, leg mass and flexibility on success in university student elite gymnasts. It was conducted on Haliç University, Marmara University, Çukurova University and University of Kırşehir Ahi Evran gymnastics teams (male and female) which took part in Turkish Intercollegiate Gymnastics Championship and, later, voluntarily participated in this study. While years of age, height and weight of male gymnasts participating in the study were $21.20 \pm 1.57,174.00 \pm 4.57$ and $67.60 \pm 6.46 \mathrm{~kg}$, respectively, the same values were $21.00 \pm 2.65$ years of age, $165.31 \pm 4.60 \mathrm{~cm}$ and $54.62 \pm 4.63 \mathrm{~kg}$ for female gymnasts, respectively. Spearman correlation analysis was performed using SPSS 22.0 package program for Windows, the level of significance was taken as 0.05 . The analysis results indicate a highly positive significant correlation $(\mathrm{r}=.761, \mathrm{p}<0.001)$ between leg volume and leg mass in male gymnasts, a highly positive significant correlation $(\mathrm{r}=.674, \mathrm{p}<0.01)$ between leg volume and leg mass in female gymnasts, a highly positive significant correlation $(r=.795, \mathrm{p}<0.001)$ between leg volume and leg mass in male and female gymnasts, a low positive significant correlation ( $\mathrm{r}=.361$, $\mathrm{p}<0.05$ ) between leg volume and success in male and female gymnasts, and a moderate positive significant correlation $(\mathrm{r}=.463, \mathrm{p}<0.05)$ between leg mass and success in male and female gymnasts. As a result, gymnastics as a sport requires a combination of speed, strength, endurance, agility, and flexibility. Speed, strength, agility and flexibility are important parameters for training and performance. In addition, an optimal amount of leg volume $(13000 \mathrm{ml}, 14000 \mathrm{ml})$ and leg mass $(13-14 \mathrm{~kg})$ contribute to success in elite gymnasts.
\end{abstract}

Keywords: Gymnasts, leg volume, leg mass, flexibility, success

\section{Introduction}

A sport branch where biomechanical properties play a significant role, gymnastics require a proportional and well-built body and muscle structure as well as a highly developed neuromuscular coordination in order to perform movements peculiar to this branch (Bagci, 2003). Gymnastics is a multifaceted sport with different performance requirements. It combines speed, strength, endurance, agility, and flexibility. Speed, strength, agility and flexibility are important parameters for training and performance (Daly, Bass, \& Finch, 2001). Flexibility is influenced by various factors such as hereditary differences in joint structures, connective tissue elasticity, muscle viscosity, reciprocal muscle coordination, and gender and body type. All individuals have different flexibility due to different muscle and ligament lengths. Because the number of connective tissues is higher in males, females are more flexible compared to males (Nalcakan, 2001).

The popularity of gymnastics grows day by day as it becomes more widespread at Turkish universities. Although some studies define physical suitability, leg volume, leg mass, physical and somatotype properties in different sport branches, no studies were found on the relationship between leg volume and leg mass in gymnasts. In this respect, this analyzes the effect of the relationship among leg volume, leg mass and flexibility on success in elite gymnasts.

\section{Material and Methods}

This study was carried out on Halic University, Marmara University, Cukurova University and University of Kursehir Ahi Evran gymnastics teams [male $(n=20)$ and female $(n=16)$ ] which took part in Koç Fest Turkish Intercollegiate 
Gymnastics Championship and, later, voluntarily participated in this study. While years of age, height and weight of male gymnasts participating in the study were $21.20 \pm 1.57,174.00 \pm 4.57$ and $67.60 \pm 6.46 \mathrm{~kg}$, respectively, the same values were $21.00 \pm 2.65$ years of age, $165.31 \pm 4.60 \mathrm{~cm}$ and $54.62 \pm 4.63 \mathrm{~kg}$ for female gymnasts, respectively.

\subsection{Calculation of Leg Volume and Mass}

Femur, calf and feet were measured in order to calculate leg volume. The distance between tibial point and inguinal fold was calculated to find the femur volume. After this distance was measured for each 10 percentile of total length, as defined by frustum sign model method, volumes for each 10 percentile (Formula 1) and volumes of all other parts were summed to calculate total femur volume (Formula 2). In order to find calf volume, the distance between tibial point and medial malleolus point was first calculated. After this distance was measured for each 10 percentile of total length, as defined by frustum sign model method, volumes for each 10 percentile (Formula 1) and volumes of all other parts were summed to calculate total calf volume (Formula 3). Foot volume was measured using medial malleolus (Ozkan, \& İsler, 2010; Sukul, Den Hoed, Johannes, Van Dolder, \& Benda, 1993).

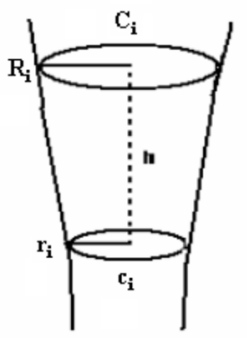

$$
\begin{array}{ll}
R_{i}=\frac{C_{i}}{2 \pi}, & r_{i}= \\
\frac{c_{i}}{2 \pi} & \\
& V_{u}=\sum_{i=1}^{10} \frac{\pi}{3} h\left(R_{i}^{2}+R_{i} r_{i}+r_{i}^{2}\right)
\end{array}
$$

$$
V_{b}=\sum_{i=1}^{10} \frac{\pi}{3} h\left(R_{i}^{2}+R_{i} r_{i}+r_{i}^{2}\right)
$$

Figure 1. Calculation of Leg Volume

$$
\begin{aligned}
& \mathrm{V}_{\mathrm{u}}=\text { Femur volume } \\
& \mathrm{V}_{\mathrm{b}}=\text { Calf volume } \\
& \mathrm{R}_{\mathrm{i}}=\text { Radius of wide part of } 10 \text { percentile } \\
& \mathrm{r}_{\mathrm{i}}=\text { Radius of narrow part of } 10 \text { percentile } \\
& \mathrm{C}_{\mathrm{i}}=\text { Diameter of wide part of } 10 \text { percentile } \\
& \mathrm{c}_{\mathrm{i}}=\text { Diameter of narrow part of } 10 \text { percentile } \\
& \mathrm{h}=\text { Distance between narrow and wide parts of } 10 \text { percentile }
\end{aligned}
$$

\subsubsection{Calculation of Foot Volume}

While the elliptic surface of cross section area ( $\mathrm{Si}$ ) in each part is calculated using Formula 4, volumes of other consecutive parts between the lines were calculated using Frustum model. When calculating foot volume, hi, i+1 is the distance between consecutive foot parts (Formula 5), and $\mathrm{h}$ value, which is $\mathrm{L} 3 / 2$, is the height between line 1 and foot sole, and it varies depending on the foot. On the other hand, h value between third and fourth parts is L1/2, which varies depending on the foot. The volume of fifth part is calculated using elliptic parabolic Formula 6, while total foot volume is calculated by summing volumes of all parts (Formula 6) (Ozkan, \& İsler, 2010; Mayrovitz, Sims, Litwio, \& Pfister, 2005). 


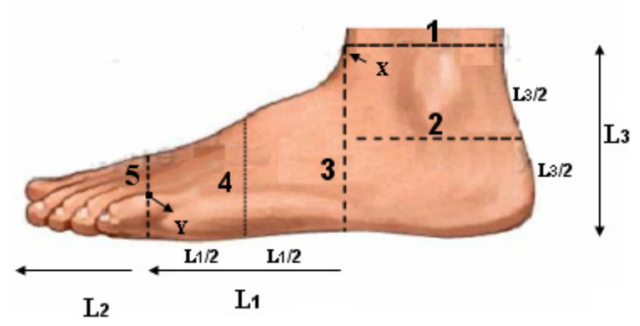

Figure 2. Calculation of Foot Volume

$\mathrm{S}_{\mathrm{i}}=$ Cross section area

$$
\begin{aligned}
& S_{i}=\prod W_{i} D_{i} / 4 \\
& V_{i}=\left(h_{i, I+1} / 3\right)\left\{S_{i}+S_{i+1}+\left(S_{i} S_{i+1}\right)^{1 / 2}\right\} \\
& V_{5}=\prod L_{2} W_{5} D_{5} / 8
\end{aligned}
$$

$\mathrm{W}_{\mathrm{i}}=$ Maximum width

$\mathrm{D}_{\mathrm{i}}=$ Maximum depth

$\mathrm{V}_{\mathrm{i}}=$ Volume

$\mathrm{h}_{\mathrm{i}}=$ Height

$\mathrm{V}_{5}=$ Total foot volume

The foot volume was defined by drawing lines between foot sole and medial malleolus point, volumes of different foot parts were calculated as mentioned above, and, finally, volumes of all parts were summed to calculate total foot volume (Formula 7).

$$
\begin{aligned}
& \mathrm{V}_{\mathrm{a}}=\mathrm{V} 1+\mathrm{V} 2+\mathrm{V} 3+\mathrm{V} 4+\mathrm{V} 5 \\
& \mathrm{~V}_{\mathrm{a}}=\text { Foot volume } \\
& \mathrm{V}_{1}=\text { Volume of first part } \\
& \mathrm{V}_{2}=\text { Volume of second part } \\
& \mathrm{V}_{3}=\text { Volume of third part } \\
& \mathrm{V}_{4}=\text { Volume of fourth part } \\
& \mathrm{V}_{5}=\text { Volume of fifth part }
\end{aligned}
$$

\subsubsection{Calculation of Leg Mass}

Femur, calf and feet were measured in order to calculate leg mass. The distance between tibial point and inguinal fold was calculated for the femur. The distance between tibial point and medial malleolus point was calculated for the calf. Finally, the foot was first measured using medial malleolus, and later Havanan model method (Ozkan, \& İsler, 2010; Kwon, 1998). "Leg Volume and Mass Calculation Program” developed by Marangoz and Ozbalc1 (2017) was used for calculation. 


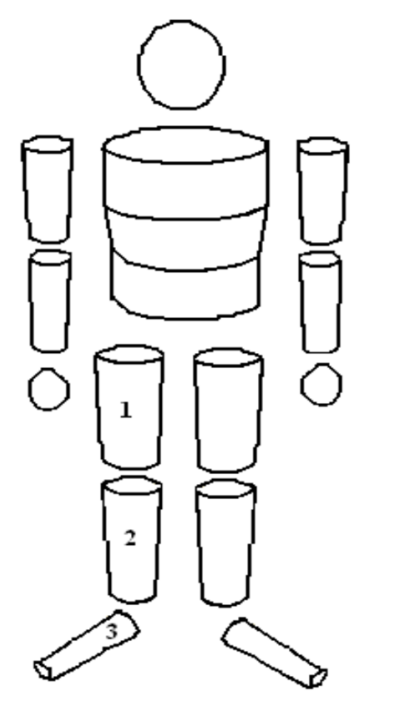

Figure 3. Hanavan Model Method

$$
m=0.074 V A+0.138 U C ̧-4.641
$$

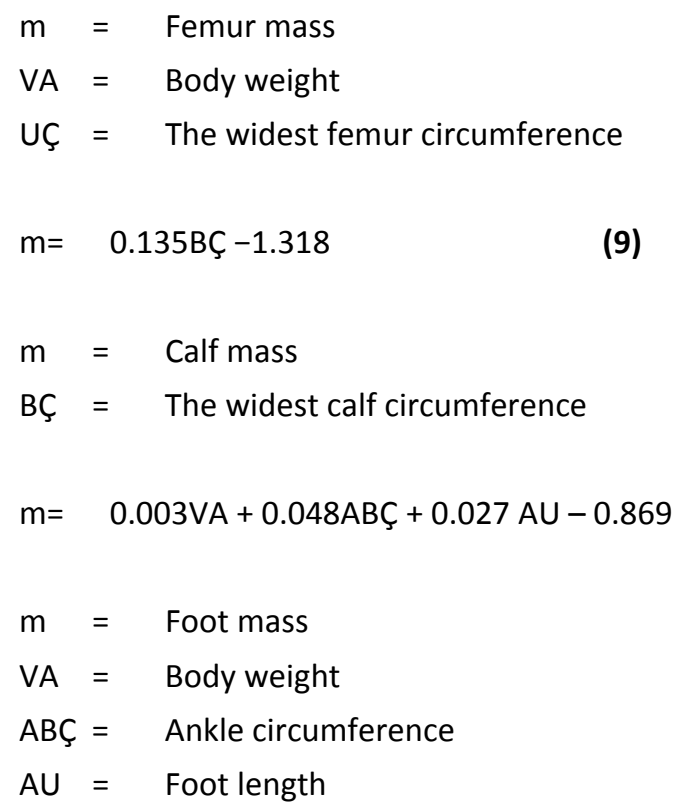

\section{(10)}

\subsection{Calculation of Flexibility}

A test table at a dimension of $35 \mathrm{~cm}$ length, $45 \mathrm{~cm}$ width and $32 \mathrm{~cm}$ height was used for Sit and Reach Test in order to measure their muscle flexibility (Raven, Gettman, Pollock, \& Cooper, 1976). Prior to the flexibility measurement, the gymnasts were given 15 minutes for a warm-up and stretching session. Lower extremity and lumbal extensor flexibility of the gymnasts were assessed based on sit-and-reach test. The gymnasts were positioned in a long sitting position with their ankles at a 90 degree angle and their naked soles touching the sit-and-reach table. They were asked to reach forward as far as possible with their hands before their body and without bending their knees and to wait for 2 seconds at this point. The point to which their bodies reached on the ruler on the test table was recorded in centimeters. The measurer stood by the gymnast to prevent them from bending their knees. Finally, the measurement was repeated twice, and the highest value was recorded (Tamer, 2000).

\subsection{Statistical Analyses}

In this study, descriptive statistics were obtained and Spearman correlation analysis was performed using SPSS 22.0 package program for Windows. The level of significance was taken as 0.05 .

\section{Findings}

Table 1. Descriptive Statistics of the Study

\begin{tabular}{lcccc}
\hline & \multicolumn{2}{c}{ Male } & & Female \\
\cline { 2 - 5 } \multicolumn{1}{c}{ Variables } & $\mathrm{N}$ & $\mathrm{x} \pm \mathrm{sd}$ & $\mathrm{N}$ & $\mathrm{x} \pm \mathrm{sd}$ \\
\hline Years of age & 20 & $21.20 \pm 1.57$ & 16 & $21.00 \pm 2.65$ \\
Height & 20 & $174.00 \pm 4.57$ & 16 & $165.31 \pm 4.60$ \\
Weight & 20 & $67.60 \pm 6.46$ & 16 & $54.62 \pm 4.63$ \\
Leg Volume & 20 & $12982.01 \pm 2931.93$ & 16 & $11614.38 \pm 1182.74$ \\
Leg mass & 20 & $13.65 \pm 1.96$ & 16 & $11.89 \pm 1.079$ \\
Flexibility & 20 & $38.35 \pm 5.69$ & 16 & $38.03 \pm 7.00$ \\
\hline
\end{tabular}


Table 2. Descriptive Statistics of the Gymnasts in Highest Ranking Teams (First 3 places)

\begin{tabular}{lcccl}
\hline \multirow{2}{*}{ Variables } & \multicolumn{2}{c}{$\begin{array}{c}\text { Haliç University } \\
\text { (Male and Female Team) }\end{array}$} & \multicolumn{2}{c}{$\begin{array}{c}\text { Marmara University } \\
\text { (Male and Female Team) }\end{array}$} \\
\cline { 2 - 5 } & $\mathrm{N}$ & $\mathrm{x} \pm \mathrm{sd}$ & $\mathrm{N}$ & \multicolumn{1}{c}{$\mathrm{x} \pm \mathrm{sd}$} \\
\hline Years of age & 7 & $171.42 \pm 7.78$ & 9 & $171.44 \pm 7.66$ \\
Height & 7 & $63.00 \pm 11.87$ & 9 & $\mathbf{6 5 . 0 0} \pm 7.81$ \\
Weight & 7 & $\mathbf{1 3 0 4 0 . 7 8 \pm 1 2 8 0 . 0 4}$ & 9 & $\mathbf{1 3 2 5 6 . 8 9} \pm \mathbf{3 6 9 8 . 4 7}$ \\
Leg volume & 7 & $\mathbf{1 3 . 4 1} \pm \mathbf{1 . 4 7}$ & 9 & $\mathbf{1 4 . 0 4} \pm \mathbf{3 6 9 8 . 4 7}$ \\
Leg mass & 7 & $\mathbf{3 7 . 3 5} \pm \mathbf{3 . 4 9}$ & 9 & $\mathbf{2 0 . 8 8} \pm \mathbf{2 . 3 2}$ \\
Flexibility & 7 & & &
\end{tabular}

Table 3. Descriptive Statistics of the Gymnasts in Lower Ranking Teams (First 3 places)

\begin{tabular}{lcccc}
\hline \multirow{2}{*}{ Variables } & \multicolumn{2}{c}{$\begin{array}{c}\text { Çukurova University } \\
\text { (Male and Female Team) }\end{array}$} & \multicolumn{2}{c}{$\begin{array}{c}\text { Kirşehir Ahi Evran University } \\
\text { (Male and Female Team) }\end{array}$} \\
\cline { 2 - 5 } & $\mathrm{N}$ & $\mathrm{x} \pm \mathrm{sd}$ & $\mathrm{N}$ & $\mathrm{X} \pm \mathrm{sd}$ \\
\hline Years of age & 9 & $20.55 \pm 1.50$ & 11 & $22.27 \pm 2.79$ \\
Height & 9 & $169.55 \pm 4.74$ & 11 & $168.72 \pm 5.65$ \\
Weight & 9 & $59.77 \pm 9.56$ & 11 & $60.18 \pm 6.16$ \\
Leg volume & 9 & $\mathbf{1 2 1 9 6 . 3 6} \pm \mathbf{1 9 9 4 . 0 5}$ & 11 & $\mathbf{1 1 3 7 3 . 2 3} \pm \mathbf{1 6 8 6 . 3 6}$ \\
Leg mass & 9 & $\mathbf{1 2 . 1 8} \pm \mathbf{1 . 6 3}$ & 11 & $\mathbf{1 2 . 1 3} \pm \mathbf{1 . 2 5}$ \\
Flexibility & 9 & $\mathbf{3 9 . 9 4} \pm \mathbf{8 . 8 6}$ & 11 & $\mathbf{3 7 . 4 5} \pm \mathbf{5 . 4 6}$ \\
\hline
\end{tabular}

Table 4. The Effect of the Relationship Among Leg Volume, Leg Mass and Flexibility on Success for Both Genders in Elite Gymnasts

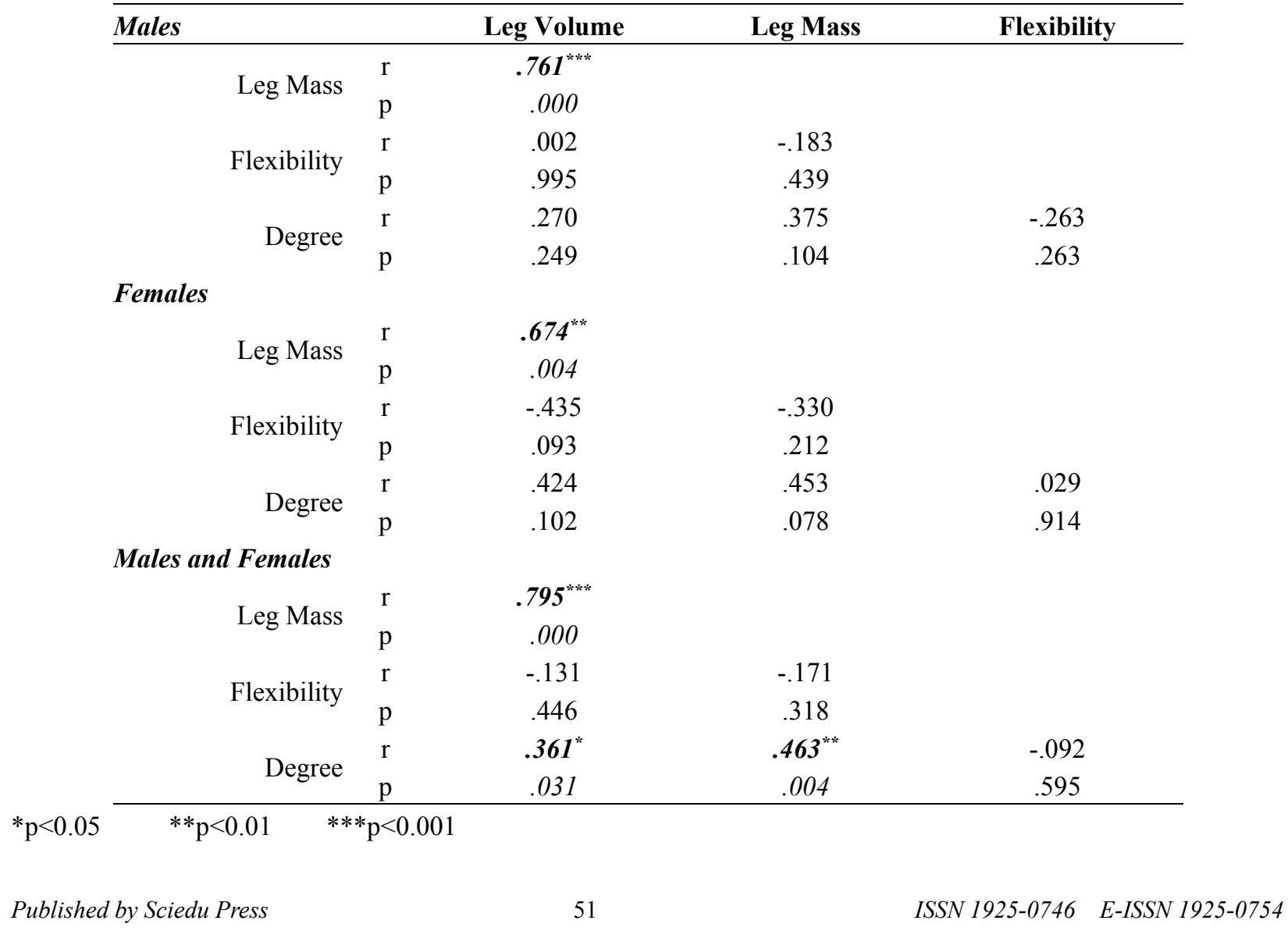


The effect of the relationship among leg volume, leg mass and flexibility for both genders in elite gymnasts were compared as shown in Table 4 . The analysis demonstrates:

a highly positive significant correlation $(\mathrm{r}=.761, \mathrm{p}<0.001)$ between leg volume and leg mass in male gymnasts,

a highly positive significant correlation $(\mathrm{r}=.674, \mathrm{p}<0.01)$ between leg volume and leg mass in female gymnasts,

a highly positive significant correlation $(\mathrm{r}=.795, \mathrm{p}<0.001)$ between leg volume and leg mass in male and female gymnasts, a low positive significant correlation $(\mathrm{r}=.361, \mathrm{p}<0.05)$ between leg volume and success in male and female gymnasts and a moderate positive significant correlation $(\mathrm{r}=.463, \mathrm{p}<0.05)$ between leg mass and success in male and female gymnasts.

\section{Discussion}

When parameters of highest and lower ranking teams in Koç Fest Turkish Intercollegiate Gymnastics Championship such as years of age, height, weight, leg volume, leg mass and flexibility are analyzed, it was observed in teams ranking in the first three places that Haliç University gymnastics team had an average weight of $63.00 \pm 11.87 \mathrm{~kg}$, an average leg volume of $13040.78 \pm 1280.04 \mathrm{ml}$, an average leg mass of $13.41 \pm 1.47 \mathrm{~kg}$, and an average flexibility of $37.35 \pm 3.49 \mathrm{~cm}$. On the other hand, Marmara University gymnastics team had an average weight of $168.72 \pm 5.65 \mathrm{~kg}$, an average leg volume of $13256.89 \pm 3698.47 \mathrm{ml}$, an average leg mass of $14.04 \pm 3698.47 \mathrm{~kg}$, and an average flexibility of $20.88 \pm 2.32 \mathrm{~cm}$.

When it comes to lower ranking teams, Çukurova University gymnastics team had an average weight of $59.77 \pm 9.56$ $\mathrm{kg}$, an average leg volume of $12196.36 \pm 1994.05 \mathrm{ml}$, an average leg mass of $12.18 \pm 1.63 \mathrm{~kg}$, and an average flexibility of $39.94 \pm 8.86 \mathrm{~cm}$, while University of Kırşehir Ahi Evran gymnastics team had an average weight of $60.18 \pm 6.16 \mathrm{~kg}$, an average leg volume of $11373.23 \pm 1686.36 \mathrm{ml}$, an average leg mass of $12.13 \pm 1.25 \mathrm{~kg}$, and an average flexibility of $37.45 \pm 5.46 \mathrm{~cm}$.

In terms of above-mentioned parameters, a low positive significant correlation $(\mathrm{r}=.361, \mathrm{p}<0.05)$ was found between leg volume and success and a moderate positive significant correlation $(\mathrm{r}=.463, \mathrm{p}<0.05)$ between leg mass and success. This demonstrates that the gymnasts in higher ranking teams have a higher amount of leg volume and mass. Even though the flexibility of gymnasts in lower ranking teams was higher, no significant correlation was found between success and flexibility. Gymnastics is an anaerobic sport branch in which flexibility bears importance. Because the long duration of stretching exercises and a high amount of repeats negatively influence performance during warm-up prior to a competition, it may lead to lower strength for gymnasts (Coknaz, Yildirim, \& Ozengin, 2008).

\section{Conclusion}

In conclusion, gymnastics brings speed, strength, endurance, agility and flexibility together. Speed, strength, agility and flexibility are important parameters for training and performance. It can be argued that an optimal amount of leg volume $(13000 \mathrm{ml}, 14000 \mathrm{ml})$ and mass $(13 \mathrm{~kg}, 14 \mathrm{~kg})$ in elite gymnasts influence performance positively. Additionally, no significant correlation was found between success and flexibility even though the flexibility of gymnasts in lower ranking teams was higher. Because the long duration of stretching exercises and a high amount of repeats negatively influence performance during warm-up prior to a competition and lead to a lower strength for gymnasts, they are recommended to perform stretching exercises for a shorter duration such as $15-20$ seconds as this may increase their chance of winning and reduce the risk of injury.

\section{References}

Bagci, E. (2003). The comparasion of some physical and conditional features between gymnastics sportswomen between 9-11 ages and the same ages rhytmic gymnastics sportswomen. Master Thesis, Gazi University, Ankara.

Coknaz, H., Yildirim, N. Ü., \& Ozengin, N. (2008). The effects of different stretching durations on performance in artistic gymnast. Ankara University faculty of sport sciences spormetre journal of physical education and sport sciences, 6(3), 151-157.

Daly, RM., Bass, SL., \& Finch, CF. (2001). Balancing the risk of injury to gymnasts: how effective are the counter measures? British journal of sports medicine, 35(1), 8-19. http://dx.doi.org/10.1136/bjsm.35.1.8

Kwon, Y.H. (1998). Modified Hanavan Model. Retrieved 08.9.2016 from 
http://www.kwon3d.com/theory/bspeq/hanavan.html/

Marangoz I., \& Ozbalcı U. (2017). Leg Volume and Mass Calculation Program in Sports. The Journal of Academic Social Science, 5(48), 223-231. https://doi.org/10.16992/ASOS.12308

Mayrovitz, H. N., Sims, N., Litwio, B., \& Pfister, S. (2005). Foot volume estimates based on a georietric algorithm in comparison to water displacement. lymphology, 38, 20-2.

Nalcakan, GR. (2001). The relationship between isokinetic knee strength and vertical jump height in volleyball players. Master Thesis, Ege University, İzmir.

Ozkan, A., \& Kin İsler A. (2010). Relationship of leg volume, leg mass, anaerobic performance and isokinetic strength in American football players. Ankara University faculty of sport sciences spormetre journal of physical education and sport sciences, 8(1), 35-41.

Raven, PB., Gettman, LR., Pollock, ML., \& Cooper, KH. (1976). A physiological evaluation of professional soccer players. British Journal of Sports Medicine, 10(4), 209-216. http://dx.doi.org/10.1136/bjsm.10.4.209

Sukul, DK., Den Hoed, P T., Johannes, EJ., Van Dolder, R., \& Benda, E. (1993). Direct and indirect methods for the quantification of leg volume: comparison between water displacement volumetry, the disk model method and the frustum sign model method, using the correlation coefficient and the limits of agreement. Journal of biomedical engineering, 15(6), 477-480. https://doi.org/10.1016/0141-5425(93)90062-4

Tamer, K. (2000). Sporda Fiziksel Fizyolojik Performansın Ölçülmesi ve Değerlendirilmesi. Ankara. 